\title{
Survei kecacingan pada anak dengan riwayat alergi di sekolah dasar yang terdapat di Kecamatan Sario Kota Manado
}

\author{
${ }^{1}$ Sitha Sartika \\ ${ }^{2}$ Greta J. P. Wahongan \\ ${ }^{2}$ Josef S.B. Tuda
}

\author{
${ }^{1}$ Kandidat Skripsi Fakultas Kedokteran Universitas Sam Ratulangi Manado \\ ${ }^{2}$ Bagian Parasitologi Klinik Fakultas Kedokteran Universitas Sam Ratulangi Manado \\ Email: sithasartika@yahoo.com
}

\begin{abstract}
Helminthic infection is an important public health problem in several parts of the world. It was noted that during 2012 in Manado there were 104 cases of helminthic infection. There is similarity between the immunological pathways from helminthic infection and allergy which is characterized by increases Th2. But in chronic helminthic infection, excessive immune response can be suppressed and therefore contribute to reduced susceptible to allergies. This study aims to see the survey of helminthic infection in students with allergy history in Sario District, Manado. This study is a cross sectional descriptive study. ISAAC questionnaire was distributed to 138 students and after being analyzed, 37 of them are allergy positive, and 16 of them are willing to participate in this study. Feces and blood were obtained as sample. From 16 feces samples, it was found that there is no helminthic infection in any of them. From 16 blood samples, it was obtained that there are 2 $(12,5 \%)$ samples with eosinophilia. Conclusion: based on study that was done, helmintic infection survey found all negative result in students with allergy history in Sario District, Manado
\end{abstract}

Keywords: allergy, helminthic infection, elementary school students

\begin{abstract}
Abstrak: Infeksi kecacingan merupakan masalah kesehatan masyarakat yang penting di beberapa bagian dunia. Di Manado pada tahun 2012 tercatat ada 104 kasus kecacingan. Ada kemiripan jalur imunologi antar kecacingan dan alergi yang ditandai dengan peningkatan Th2. Namun, pada infeksi cacing kronis, respon imun yang berlebihan tersebut dapat ditekan hingga berpengaruh pada berkurangnya kerentanan terhadap alergi. Penelitian ini bertujuan untuk mengetahui survei kecacingan pada anak dengan riwayat alergi di SD yang terletak di Kecamatan Sario Kota Manado. Jenis penelitian ini ialah deskriptif dengan desain potong lintang. Sebanyak 138 kuesioner ISAAC dibagikan dan 37 diantaranya menunjukan hasil positif alergi. Dari 37 anak dengan alergi, 16 bersedia menjadi sampel penelitian. Dilakukan pengambilan sampel berupa feses dan darah untuk diperiksa kecacingan dan eosinofilia. Dari 16 feses yang diperiksa semua menunjukan hasil negatif kecacingan. Dari 16 sampel darah yang diperiksa ditemukan $2(12,5 \%)$ diantaranya mengalami eosinofilia. Simpulan: berdasarkan penelitian yang dilakukan, survei kecacingan pada anak dengan riwayat alergi di Kecamatan Sario, Kota Manado menunjukan hasil tidak ditemukan adanya infeksi kecacigan.
\end{abstract}

Kata kunci: alergi, kecacingan, anak sekolah dasar

Infeksi kecacingan merupakan masalah kesehatan masyarakat yang penting di beberapa bagian dunia, terutama di negara berkembang dan negara miskin di dunia. Berdasarkan data dari World Health Organisation (WHO) pada tahun 2012 
memperkirakan lebih dari 1,5 miliar orang atau $24 \%$ dari populasi dunia terinfeksi dengan cacing yang ditularkan melalui tanah yang ditularkan di seluruh dunia. ${ }^{1}$

Indonesia merupakan daerah tropis yang menjadi salah satu faktor risiko yang berpengaruh kuat terhadap risiko terjadinya infeksi kecacingan. Diperkirakan lebih dari $60 \%$ anak-anak di Indonesia menderita infeksi kecacingan. Data Dinas Kesehatan Manado, jumlah kasus kecacingan dari bulan Januari sampai Desember tahun 2012 sebanyak 102 kasus. $^{2}$

Terjadinya infeksi kecacingan sering dihubungkan dengan kondisi lingkungan, sosioekonomi dan tingkat pendidikan. Anak-anak lebih banyak berisiko menderita infeksi kecacingan karena aktifitasnya yang lebih banyak seperti bermain dan kontak dengan tanah, sehingga sanitasi yang buruk dan kondisi lingkungan yang jelek menjadi faktor penting penyebab infeksi kecacingan. ${ }^{3}$

Faktor lingkungan juga merupakan faktor risiko utama pencetus alergi, seperti di perkotaan yang memiliki kondisi lingkungan yang beragam berupa buruknya kualitas udara dan berubah pola hidup masyarakat. World Health Organization (WHO) memperkirakan alergi terjadi pada 5-15\% populasi anak di seluruh dunia. ${ }^{4}$

Departemen Kesehatan Indonesia memperkirakan terdapat peningkatan prevalensi asma seiring bertambahnya usia, dimana umur 5-14 tahun mempunyai prevalensi asma terbesar ketiga di Indoensia dengan presentase 3,9\%. Kejadian asma di perkotaan umumnya lebih tinggi dibandingkan dengan di pedesaan, karena pola hidup di kota besar meningkatkan risiko terjadinya asma.,

Respon imun manusia terhadap kecacingan berkaitan dengan peningkatan kadar IgE dan eosinofil jaringan, yang menstimulasi produksi Th2 yang berlebihan. Pada infeksi cacing kronis, respons imun yang berlebihan ini dapat ditekan sehingga berpengaruh pada berkurangnya kerentanan terhadap alergi. ${ }^{10}$

Kecamatan Sario merupakan salah satu kecamatan yang berada di Kota Manado.
Memiliki luas wilayah lebih dari 175.25 Ha. Dengan jumlah penduduk 24.549 jiwa, terdiri dari 12.05 laki-laki dan 12.524 perempuan. Kecamatan Sario memiliki 7 kelurahan. Terdapat 16 sekolah dasar yang terletak di Kecamatan Sario dengan jumlah siswa sebanyak $2.103 .^{7,8}$

Berdasarkan pembahasan di atas maka penulis ingin mengetahui survei kecacingan pada anak dengan riwayat alergi di sekolah dasar yang terdapat di Kecamatan Sario Kota Manado.

\section{METODE PENELITIAN}

Penelitian ini merupakan sebuah penelitian deskriptif yang dilakukan secara cross sectional. Penelitian ini dilakukan pada bulan September - Desember pada anak SD yang terdapat di Kecamatan Sario Kota Manado. Kuesioner ISAAC (International Study of Asthma and Allergy in Childhood) dibagikan pada anak kelas 16. Pada anak kelas 1-4 kuesioner ditujukan pada orang tua, sedangkan pada anak kelas 5-6 diisi langsung oleh anak. Adapun cara pemilihan sample dalam penelitian ini adalah dengan memasukkan semua anak yang terdeteksi menderita alergi selama masa penelitian.

Kecacingan dalam penelitian ini adalah suatu keadaan dimana pasien terinfeksi dengan cacing golongan nematoda usus, dimana diagnosisnya ditegakkan dengan pemeriksaan feses. Riwayat alergi adalah suatu keadaan dimana pasien telah mengalami riwayat alergi sebelumnya seperti asma dan rinitis yang ditemukan dengan menggunakan kuesioner ISAAC (International Study of Asthma and Allergy in Childhood). Sedangkan untuk pengukuran eosinofilia digunakan alat analisa darah Sysmex. Data yang didapatkan disajikan dalam bentuk tabel frekuensi.

\section{HASIL PENELITIAN}

Penelitian dilakukan di SD GMIM 30 Sario yang memenuhi kriteria inklusi. Dari 138 kuesioner yang dibagikan, ada 126 kuesioner yang diperoleh kembali. Dari 126 kuosioner yang diidentifikasi, 
ditemukan 37 positif mengalami alergi. Diberikan informed consent pada 37 orang tua dari anak dan yang setuju untuk dilakukan penelitian ini adalah 16 anak. Pada 16 anak ini diambil sampel berupa feses untuk dilihat apakah ada infeksi cacing dan diambil juga darah untuk diperiksa apakah terjadi eosinofilia untuk memastikan adanya alergi. Berdasarkan hasil pemeriksaan feses yang telah dilakukan di Laboratorium Parasitologi Klinik Fakultas Kedokteran Unsrat didapatkan keseluruhan responden tidak ada yang mengalami kecacingan

Tabel 1. Tabel Pemeriksaan Feses

\begin{tabular}{cccc}
\hline No & Sampel & n & $\mathbf{( \% )}$ \\
\hline 1. & Positif & 0 & $0 \%$ \\
2. & Negatif & 16 & $100 \%$ \\
& Jumlah & 16 & $100 \%$ \\
\hline
\end{tabular}

Hasil analisis darah lengkap pada 16 sampel didapatkan 2 sampel yang mengalami peningkatan eosinofil dengan presentase $12,5 \%$ dan sampel yang tidak mengalami peningkatan eosinofil sebanyak 14 sampel dengan presentase $87,5 \%$.

Tabel 2. Pemeriksaan eosinofil

\begin{tabular}{cccc}
\hline No & Sampel & $\mathbf{n}$ & $\mathbf{( \% )}$ \\
\hline 1. & eosinofilia & 2 & $12.5 \%$ \\
2. & Tidak eosinofilia & 14 & $87.5 \%$ \\
& Jumlah & 16 & $100 \%$ \\
\hline
\end{tabular}

\section{BAHASAN}

Berdasarkan hasil pemeriksaan feses terhadap 16 anak di SD GMIM 30 Sario yang memiliki penyakit alergi tidak ditemukan adanya kecacingan dan pada pemeriksaan darah untuk mengetahui kadar eosinofil ditemukan dua anak yang memiliki kadar eosinofil yang tinggi. Hal tersebut ditunjang oleh penelitian yang dilakukan Andiarsi, dkk yang menyatakan bahwa anak yang mengalami alergi cenderung lebih banyak pada anak yang tidak menderita infeksi kecacingan $(35,5 \%)$ dan sebaliknya anak yang menderita infeksi kecacingan justru lebih banyak terdapat pada anak yang tidak alergi $(18,4 \%)$. Selain itu, penelitian yang dibuat oleh Soleman, dkk menyatakan bahwa anak yang mengalami dermatitis atopi lebih banyak ditemukan pada anak yang tidak terinfeksi kecacingan. ${ }^{11,12}$

Ada kemiripan jalur imunologi antara infeksi kecacingan dan alergi yang ditandai dengan tingginya eosinofil, IgE dalam serum dan basofil serta sel mast dalam jaringan yang memugkinkan terjadinya respon hipersensitifitas. Selama infeksi cacing, produksi IgE total non spesifik menjadi meningkat berbanding lurus dengan derajat infeksinya. Banyaknya konsentrasi antibodi poliklonal ini berdampak pada jenuhnya reseptor pada permukaan sel mast, sehingga menghalangi kompleks alergen spesifik IgE mengikat pada reseptor. Hal ini yang mengakibatkan pada orang yang terinfeksi cacing cenderung akan menunjukkan hasil negatif pada pemeriksaan tes terdahadap alergen tertentu. ${ }^{11,13}$

Kejadian antara infeksi kecacingan dan alergi seringkali tidak tumpang tindih dan populasi yang terpapar oleh infeksi cacingan menunjukkan sedikit gejala alergi. ${ }^{11}$ Seperti pada penelitian ini, tidak didapatkan adanya kecacinagn pada anak dengan penyakit alergi. Pada penlitianpenelitain sebelumnya menyatakan probabilitas untuk mendeteksi parasit menigkat sekitar $60 \%$ bila hanya dilakukan satu kali pemeriksaan spesimen, namun jika pemeriksaan specimen dilakukan tiga kali maka hasil yang didapat lebih baik yaitu sekitar 95\%. ${ }^{15}$ Selain itu, penyebab lain sehingga tidak ditemukan adanya infeksi kacacingan juga berhubungan dengan kesadaran masyarakat setempat termasuk anak-anak akan sanitasi dan higienitas terhadap lingkungan, makanan dan minuman yang sudah baik.

Pada pemeriksaan darah untuk mengetahui kadar eosinofil, ditemukan $12.5 \%$ dari sampel yaitu berjumlah 2 anak yang memiliki kadar eosinofil yang tinggi dari 16 anak yang diketahui memiliki penyakit alergi. Spector, dkk dalam penelitianya menyimpulkan bahwa kadar eosinofil dapat berubah-ubah secara 
Sartika, Wahongan, Tuda: Survei kecacingan pada...

signifikan dalam sehari tanpa alergen pemicu. Dengan demikian, pemeriksaan kadar eosinofil yang dilakukan terhadap siswa-siswi yang memiliki penyakit alergi perlu dilakukan beberapa kali dikarenakan jumlah eosinofil yang berfluktuasi sepanjang hari. ${ }^{14}$ Selain itu, pemeriksaan untuk mengetahui apakah alergi atau tidak juga bisa dilakukan dengan pemeriksaan IgE dan basofil agar hasil yang didapatkan lebih spesifik.

Kelemahan penelitian adalah pada saat penandatanganan informed consent. Banyak orang tua yang tidak mengijinkan anaknya disuntik untuk pengambilan sampel darah.

\section{SIMPULAN}

Dari hasil penelitian menunjukkan bahwa survei kecacingan pada anak sekolah dasar dengan riwayat alergi di SD GMIM 30 Sario tidak didapatkan adanya kecacingan yang ditemukan.

\section{SARAN}

Disarankan untuk melakukan penelitian dengan ukuran sampel yang lebih besar dan daerah yang lebih luas. Pendekatan yang lebih baik dengan orang tua karena banyak dari mereka yang tidak mengizinkan anaknya ikut serta dalam penelitian. Selain itu, dapat dilakukan penelitian analitik untuk mengetahui kecacingan pada anak dengan riwayat alergi di sekolah dasar yang terdapat di Kota Manado.

\section{DAFTAR PUSTAKA}

1. Tangel F, Tuda J, Pijoh V. Kecacingan Usus pada Anak SD GMIM Budo di Dsa Budo Kecamatan Wori. 2016;4(1):70-75.

2. Limbanadi EM, Rattu Joy AM, Pitoi M. Hubungan Antara Status Ekonomi, Tingkat Pendidikan dan Pengetahuan Ibu Tentang Penyakit Kecacingan Dengan Infestasi Cacing Pada Siswa Kelas IV, V dan VI di SD Negeri 47 Kota Manado.

3. Harminarti N, Supali T, Wibowo $H$. Hubungan Infeksi Cacing Usus dan Atopi Pada Anak Sekolah Dasar.
Majalah Kedokteran Andalas. 2008;32(1).

4. Uthari LP. 2015. Penyakit Alergi. Online. Tersedia:http://eprints.undip.ac.id/463 16/2/Luh_Putu_Uthari_22010111110 084_Lap.KTI_Bab1.pdf (29 Agustus 2016)

5. Pusat Data dan Informasi Kesehatan RI. Infodatin

6. Oemiati R, Sihombing M, Qomariah. Faktor-Faktor Yang Berhubungan Dengan Penyakit Asma di Indonesia. Media Litbang Kesehatan. 2001;XX(1).

7. Silalahi RHB, Wistiani, Dharmana E. Jumlah Eosinofil Pada Anak dengan Soil Transmitted Helminthiasis yang Berusia 6-10 Tahun. Sari Pediatri. 2014;16(2).

8. Badan Pusat Statistik Kota Manado. Manado Dalam Angka. 2015

9. Badan Pusar Statistik Kota Manado, Sulawasi Utara. Sario Dalam Angka. 2008

10. Joprang SF, Supali T. Peran Cacing Usus dalam Menekan Kejadian Atopi. Majalah Kedokteran FK UKI. 2008;XXVI(1).

11. Andiarsa D, Melianie G, Hidayat $S$. Alergi dan Infeksi Cacing Pada Anak Sekolah Dasar Negeri Kampung Baru Kecamatan Hilir Kabupaten Tanah Bambu Dengan Status Ekonomi Yang Berbeda. Jurnal Buski. 2013;4(3):115-120.

12. Soleman MN, Wahyuni S, Ilyas FS, Amin S, Satriono R, Tabri F. Infeksi Cacing Tidak Berpengaruh Terhadap Transforming Growth Factor (TGF) $\beta$ Dan Kejadian Dermatitis Atopic Pada Anak. Jurnal Kedokteran Brawijaya. 2015;28(3):217-221.

13. Andiarsa D, Hairani H, Meliyane G, Fakhrizal D. Infeksi Cacing Imunitas dan Alergi. Jurnal Buski. 2012;4(1):47-52.

14. Spector S, Tan R, Malinowski A. Labile Blood Eosinophilia in Asthma. Chest Journal. 2011;140(4):214-216.

15. Martin H, Koella JC. Multiple Stool Examination For Ova And Parasites And Rate Of False-Negatif Result. $J$ Clin Microbiol. 1993;31(11):3004-5. 